\author{
Jacek Strojny \\ Instytut Gospodarki \\ Wyższa Szkoła Informatyki i Zarządzania, Rzeszów
}

\title{
Zarządzanie przedsiębiorcze w dobie globalizacji - perspektywa kulturowa
}

Wydaje się, że w XXI wieku nauki społeczne w coraz większym stopniu zajmować się będą zjawiskiem kształtowania się społeczeństwa globalnego. Rzeczywistość zglobalizowana, w wyniku intensywnych przemian społeczno-gospodarczych staje się faktem nie podlegającym dyskusji. Działalność gospodarcza, poprzez radykalne zmniejszenie kosztów komunikacji i zmniejszenie barier przepływu kapitału, przybiera obecnie nowe, globalne formy funkcjonowania. Jest zatem oderwana od ograniczeń narzucanych przez systemy państwowe. Można już mówić o rynku globalnym, przedsiębiorstwach globalnych, handlu globalnym, finansach globalnych, a coraz częściej nawet globalnym rynku pracy. Produkcja, wymiana i konsumpcja w wyniku liberalizacji (zniesienia barier obiegu) mogą być rozproszone i elastycznie przenoszone w dowolny punkt globu. Sprawia to, że dotychczasowe relacje państwo - przedsiębiorstwo zmieniły się w sposób diametralny. Obecnie to państwa (władze państwowe lub samorząd terytorialny) zmuszone są do zabiegania o inwestorów, stwarzając poprzez swoją politykę warunki jak najbardziej sprzyjające nowym inwestycjom. Coraz większego znaczenia nabiera również zmiana w relacjach państwo - obywatel. Swoboda przepływu ludzi powoduje, że jednostki mają możliwość wyboru swojego miejsca zamieszkania i miejsca pracy. Dotyczy to zarówno osób o wysokich, jak i niskich kwalifikacjach, ale zawsze przedsiębiorczych zdolnych do zaakceptowania ryzyka i dążących do poprawy swojej sytuacji ekonomicznej. Tworzy się w ten sposób społeczeństwo mobilne, nie związane z systemem terytorialnym. Otwierają się także nowe obszary konkurencji, które obejmują: tworzenie przez państwa regulacji sprzyjających osiedlaniu się i podejmowaniu pracy na ich terytorium, wzrost konkurencji na rynku pracy pomiędzy mobilnymi pracobiorcami oraz pomiędzy organizacjami o pracobiorców, którzy dysponują możliwością swobodnego przemieszczania się i wyboru ofert pracy w różnych częściach świata.

Proces globalizacji ma niezwykle istotne znaczenie, gdyż dotyka wszystkich sfer życia społecznego-gospodarczego. Przede wszystkim jednak determinuje on coraz większą zmienność, można powiedzieć zmienność totalną, wszechobecną i nieuniknioną. Stwarza to sytuację, w której jedyne, czego można być pewnym, jest to, że w otoczeniu ${ }^{2}$ zaistnieje zmiana. Pojawić się ona może w każdym z obszarów otoczenia. Najczęściej otoczenie, w którym funkcjonują organizacje, dzieli się na dwa główne zbiory czynników: otoczenie

\footnotetext{
${ }^{1}$ Por. E. Cziomer, L. W. Zyblikiewicz, Zarys współczesnych stosunków międzynarodowych, Wydawnictwo Naukowe PWN, Warszawa-Kraków 2001, s. 187.

${ }^{2}$ Otoczenie traktować można jako zbiór czynników wyznaczających funkcjonowanie organizacji lub jej elementów (por. J. Łucewicz, Socjologiczne spojrzenie na organizację, Wydawnictwo im. Oskara Langego we Wrocławiu, Wrocław 1997).
} 
ogólne i otoczenie konkurencyjne ${ }^{3}$. Pierwsze obejmuje takie obszary zmian, jak: uwarunkowania ekonomiczne, technologiczne, społeczne, demograficzne, polityczne i prawne oraz międzynarodowe. Jest to oczywiście podział umowny, nie pozwalający na wyznaczenie ścisłych granic pomiędzy tymi obszarami. Niezależnie od tego, należy stwierdzić, że w każdym z obszarów zachodzą zjawiska o istotnej sile wpływu, często trudne nie tylko do interpretacji, ale wręcz do odczytania, wyodrębnienia. Zmieniają się przecież ciągle uwarunkowania ekonomiczne, na które wpływ mają już nie tylko państwa, ale również cały szereg czynników o charakterze ponadnarodowym. Tworzenie się globalnych sieci naukowobadawczych dynamizuje postęp naukowy, przez co skraca się czas przygotowania nowych wynalazków, a ścisła współpraca z biznesem pozwala na szybkie wdrożenie nowego produktu. Starzenie się rozwiązań technicznych i technologicznych powoduje konieczność ciągłej modernizacji i unowocześniania stosowanych rozwiązań. Dążeniom do tworzenia ponadnarodowych struktur regionalnych towarzyszy kryzys struktur politycznych i dążenia separatystyczne. Niezwykle istotne znaczenie mają zmiany o charakterze społecznym, w tym zmiany kulturowe, dotyczące systemu wartości, postaw, wzorców zachowań, stylu życia. Powstawaniu społeczeństwa mobilnego, elastycznego towarzyszy eskalacja radykalizmu religijnego. Tak więc globalizacji gospodarki towarzyszy pękająca struktura polityczna ${ }^{4}$, a globalizacji społeczeństwa nasilenie ruchów radykalnych.

Powstawaniu ${ }^{5}$ cywilizacji globalnej towarzyszy proces tworzenia się kultury globalnej ${ }^{6}$, który z coraz większą siłą wpływa zarówno na poszczególne jednostki, jak i tworzone przez nie organizacje. Społeczności poddawane są procesom unifikacji zachowań. Można wymienić dwie główne przyczyny takiego stanu rzeczy. Po pierwsze, wzorce zachowań upowszechniane $\mathrm{z}$ niesłychaną łatwością za pomocą mediów, takich jak telewizja i Internet. Właśnie za pomocą tych kanałów ludzie w każdym niemal zakątku globu kształtowani są w coraz większym stopniu w duchu wartości o charakterze ponadlokalnym, ponadnarodowym. Co to oznacza? Przede wszystkim stwarza to sytuację, w której na kultury wytworzone $\mathrm{w}$ określonych społecznościach i charakteryzujące się określonymi parametrami ${ }^{7}$ wynikającymi z ich specyfiki, nakłada się kultura o parametrach, które mają zdolność do dominacji nad parametrami lokalnymi. Jej źródeł należy szukać w społeczeństwach, które

\footnotetext{
${ }^{3}$ Por. G. Gierszewska, M. Romanowska, Analiza strategiczna przedsiębiorstwa, Polskie Wydawnictwo Ekonomiczne, Warszawa 1998.

${ }^{4}$ Por. P. F. Drucker, Zarządzanie w czasach burzliwych, Nowoczesność, Warszawa 1995, s. 163.

5 Wydaje się, że nie ma jeszcze przesłanek pozwalających stwierdzić, że zmiany społecznogospodarcze doprowadziły już do powstania cywilizacji globalnej. Dla przykładu podać można systemy władzy państwowej, które opierają się na granicach umownych. Jeśli jednak przyjąć, że wyznacznikiem cywilizacji jest stanięcie przed szeregiem wyzwań rozwojowych, to niewątpliwie można mówić o cywilizacji globalnej. Do najważniejszych wyzwań zaliczyć można niekorzystne trendy demograficzne, wyczerpywanie się nieodnawialnych zasobów surowców energetycznych, terroryzm, walka $\mathrm{z}$ chorobami, dysproporcje w poziomie zamożności społeczeństw i grup społecznych, zagrożenie zderzeniem Ziemi z innym ciałem niebieskim, czy w końcu eksplorację kosmosu.

${ }^{6}$ Terminy cywilizacja i kultura często traktowane są jako tożsame (por. M. Pacholski, A. Słaboń, Słownik pojęć socjologicznych, Akademia Ekonomiczna w Krakowie, Kraków 1997). Zasadnym wydaje się jednak ich rozróżnienie, które zakłada, że pojęcie kultura dotyczy sfery duchowej (wartości, postawy, wzorce zachowań), zaś cywilizacja - technicznej, ekonomicznej i materialnej.

${ }^{7}$ Pojęcie kultura jest rozpatrywane wieloaspektowo i różnorodnie interpretowane przez socjologów. Spośród ponad setki definicji, na użytek niniejszego opracowania oprzeć się można na tej autorstwa B. Bergera. Wymienia on takie parametry, charakteryzujące kulturę, jak m. in: wartości, normy, postawy. Wartości traktować tutaj można, jako obiekt dążeń jednostek, jako coś, co jest uznawane za cel podejmowanych działań. To weberowskie podejście, traktujące wartości jako determinantę, czy wręcz aktywatora działań społecznych pozwala szukać właśnie w zbiorze wartości, charakterystycznych dla danej społeczności przyczyn działań podejmowanych przez jednostki, należące do tej społeczności. Zatem cel działania wynika ze zbioru wartości, przy czym zbiór ten, tak samo, jak i cele ulegają hierarchizacji.
} 
tworzą tzw. cywilizację zachodu. Oczywiście trudno jest jednoznacznie stwierdzić, jakie są przyczyny dominacji tej kultury i co sprawia, że cechuje się ona taką ekspansywnością na skalę globalną. Uproszczeniem byłoby stwierdzenie, że zdolność do rozprzestrzeniania się wartości, na których opiera się kultura zachodu, wynika z tego, że dysponuje ona własnymi kanałami dystrybucji, w postaci stworzonych przez siebie środków masowego przekazu informacji. Wydaje się, że przyczyn należy jednak szukać gdzie indziej - na przykład w teorii ewolucji Darvina. Zdolność do rozprzestrzeniania się charakteryzuje te byty, które posiadają cechy pozwalające przystosować się do zmiennych warunków funkcjonowania. Cechy te muszą być uniwersalne, a więc przydatne w każdych warunkach. Wydaje się, że to właśnie kultura zachodu charakteryzuje się największym natężeniem takich cech, przez co zdolna jest do upowszechniania się i adaptacji na podłożu o różnorodnej (w sensie geograficznym, historycznym, a nawet religijnym) specyfice. Należy tutaj zwrócić uwagę na zjawisko, które za Shumpeterem nazwać można kreatywną destrukcją ${ }^{8}$. Wynika ono z wewnętrznych sprzeczności, pojawiających się od samego początku funkcjonowania cywilizacji zachodniej?' Widoczne jest to w szeregu reformatorskich nurtów religijnych, naukowych, artystycznych, które powstawały na ruinach obalonych koncepcji i twierdzeń. Wielość ruchów religijnych wczesnego chrześcijaństwa, późniejsza reformacja, renesans, odkrycia Kopernika, wielkie odkrycia geograficzne, obraz Maneta Śniadanie na trawie, rewolucja techniczna, udział papieża w koncercie rockowym - rozwój cywilizacji zachodu obfituje w tego typu kamienie milowe, wyznaczające nowe trendy, nowe sposoby myślenia. Ta zdolność do autodestrukcji i jednocześnie tworzenia to prawdopodobnie najbardziej uzasadniona przyczyna rozpowszechniania się kultury zachodniej i jej przekształcania się w kulturę globalną ${ }^{10}$. Ale nie tylko. Drugą istotną cechą kultury zachodniej jest bowiem zdolność do selektywnego przyswajania elementów zbioru charakteryzującego inne kultury świata. Selektywność ta wynika z szeroko rozumianej atrakcyjności tych elementów. Tym właśnie należy tłumaczyć rozpowszechnienie się na całym świecie restauracji oferujących dalekowschodnią kuchnię, maskotkę misia koali czy niekonwencjonalne metody leczenia chorób. Powstaje w ten sposób koło zamachowe napędzające tworzenie się kultury globalnej - innowacyjność ${ }^{11}$.

Właśnie innowacyjnością kultury zachodniej można tłumaczyć jej zdolność do ekspansji i przekształcania się w kulturę globalną. Nie ulega wątpliwości, że ta zdolność do innowacji stanie się podstawową cechą społeczeństwa globalnego. Zmiany społecznogospodarcze już obecnie doprowadziły do sytuacji, w której szansę rozwoju ma tylko społeczeństwo wiedzy, społeczeństwo przedsiębiorcze. Możliwości rozwoju krajów czy regionów w oparciu o zasoby naturalne, położenie geograficzne, będą miały coraz mniejsze znaczenie. Podstawowym motorem rozwoju stanie się zdolność do uczenia się rozumiana zarówno w odniesieniu do jednostek, jak i organizacji. Spowoduje to oczywiście, że nowe, globalne społeczeństwo będzie o wiele bardziej konkurencyjne, innowacyjne i dynamiczne niż to miało miejsce do tej pory. Jakie będą tego skutki? Ogromne i przenikające wszystkie sfery

\footnotetext{
${ }^{8}$ Shumpeter określał przedsiębiorce, jako tego, który burzy dotychczasowy porządek, proponując jednocześnie dzięki inwencji, kreatywności nowe rozwiązanie prowadzące do rozwoju. Por. Piasecki B., Przedsiębiorczość i mała firma. Teoria i praktyka, Wydawnictwo Uniwersytetu Łódzkiego, Łódź 1997, s. 22.

${ }^{9}$ Por. A. Flis, Innowacyjność w kulturze zachodu [w:] praca zbiorowa pod redakcją M. Marcinkowskiego, Kapitalizm po polsku. Przedsiębiorca, organizacja, kultura, Księgarnia Akademicka, Kraków 1996.

${ }^{10}$ Pojęcie kultury globalnej nie powinno być utożsamiane z pojęciem kultury masowej, którą definiuje się jako ogół treści kulturowych, przekazywanych za pomocą środków masowego przekazu. Tymczasem kultura globalna powinna być raczej definiowana jako zbiór wartości, norm, postaw i wzorców zachowań przyjętych przez społeczeństwa globu.

${ }^{11}$ Termin innowacyjność to zdolność do kreowania innowacji, charakterystyczna dla określonej społeczności. Można za M. A. Westem stwierdzić, że innowacja to przełożenie nowatorskiej myśli, koncepcji na język praktyczny.
} 
życia społecznego. Po pierwsze zmianie ulegnie struktura społeczna. Eksperci, dysponujący specjalistyczną wiedzą będą stanowili grupę nadającą ton całej społeczności właśnie ze względu na zdolność do ciągłego przyswajania wiedzy. To ta grupa stanie się przedmiotem aspiracji zawodowych, animatorem kultury, źródłem wartości i wzorców zachowań. Poszczególne jednostki staną przed koniecznością ciągłego konkurowania, ciągłego doskonalenia się, działania w realiach, w których nie ma miejsca na niekompetencję i brak skuteczności.

Oczywiście wzrost konkurencyjności przeniesie się również na poziom tworzonych przez człowieka organizacji gospodarczych. Wydaje się, że to właśnie innowacja tworząca kontekst rozwoju cywilizacji globalnej stanowić będzie również determinantę rozwoju organizacji. Należałoby się zatem zastanowić, czym jest innowacja, jakie są jej cechy, czym jest warunkowana. Nie ma wątpliwości, że tworzy ona nową wartość. Za P. F. Druckerem można wskazać, że jest narzędziem przedsiębiorcy wykorzystywanym do podjęcia nowej działalności gospodarczej ${ }^{12}$. Jego zdaniem nie można innowacji traktować jako przebłysk geniuszu, ale jako efekt systematycznej, zorganizowanej pracy. Pojęcie innowacji odnosi się zatem zarówno do samego procesu wyszukiwania i wykorzystania źródeł do innowacji ${ }^{13}$ jak też efektu tego procesu, którym jest nowy wyrób (produkt lub usługa). Oczywiście nowy wyrób traktować należy jako reakcję przedsiębiorstwa na zidentyfikowaną szansę wynikającą ze zmian w otoczeniu. Należy jednak zwracać uwagę, że innowacja jest „(...) zjawiskiem zachodzącym $\mathrm{w}$ gospodarce $\mathrm{i}$ w społeczeństwie (...)"14. Oznacza to, że powinna ona powstawać w oparciu o obserwację i zrozumienie rynku. Tylko w takim wypadku ma szansę być pozytywnie odebrana i odnieść sukces rynkowy. Weryfikacja skuteczności innowacji następuje dopiero w momencie jej wprowadzenia na rynek. Zatem o tym, czy nowy produkt jest rzeczywiście innowacją nie decydują wcale jego obiektywne parametry, użycie nowoczesnych rozwiązań technicznych, itd. Co zatem decyduje? Wyłącznie ocena tych, którzy z nowym produktem zetkną się, będą go użytkowali i będą za jego pomocą zaspokajać swoje potrzeby. Jeśli będzie on zaspokajał te potrzeby w sposób, który uznany zostanie za innowacyjny, to produkt stanie się skuteczną innowacją.

Można podejrzewać, że innowacja będzie jednym z najbardziej istotnych narzędzi konkurowania na zglobalizowanym rynku. Aby organizacja zdolna była do przygotowania i wdrożenia innowacji musi zostać spełnione szereg warunków. Mają one charakter ekonomiczny, technologiczny, organizacyjny czy wreszcie społeczny. Wychodząc z założenia, że najważniejszym zasobem organizacji jest człowiek ${ }^{15}$ szczególną uwagę zwrócić należy na społeczne uwarunkowania kształtowania się organizacji przedsiębiorczej. Jak wskazuje M. Golińska-Pieszyńska ${ }^{16}$ o przedsiębiorczości jako zjawisku społecznym mówić należy $\mathrm{w}$ aspekcie jednostki, grupy społecznej oraz organizacji. Rola organizacji w kształtowaniu postaw przedsiębiorczych zatrudnionych $\mathrm{w}$ niej ludzi jest nie do przecenienia. Tworzy ona klimat pracy, kulturę organizacyjną, wyzwalającą lub hamującą przedsiębiorczość. Coraz bardziej powszechna staje się świadomość, że takie zachowanie sprzyja osiągnięciu przewagi

\footnotetext{
${ }^{12}$ Por. P. F. Drucker, Innowacja i przedsiębiorczość, Państwowe Wydawnictwo Ekonomiczne, Warszawa 1992, s. 29.

${ }^{13}$ Zdaniem P. F. Druckera źródła innowacji obejmują: zmiany demograficzne, zmiany w sposobie postrzegania, pojawienie się nowej wiedzy, pojawienie się nieoczekiwanego sukcesu lub porażki, powstanie niezgodności pomiędzy oczekiwaniami a rezultatami, powstanie potrzeby procesu czy wreszcie zaistnienie zmian w strukturze przemysłu (por. Drucker P. F., Innowacja i przedsiębiorczość, Państwowe Wydawnictwo Ekonomiczne, Warszawa 1992, s. 46-133).

${ }^{14}$ P. F. Drucker, Myśli przewodnie Druckera, Wydawnictwo MT Biznes, Warszawa 2002, s. 412

${ }^{15}$ Por. L. Kozioł, A. Piechnik-Kurdziel, J. Kopeć, Zarządzanie zasobami ludzkimi w firmie. Teoria i praktyka, Wydawnictwo Biblioteczka Pracownicza, Warszawa 2000, s. 21.

${ }^{16}$ M. Golińska-Pieszyńska, Przedsiębiorca i przedsiębiorczość - ewolucja pojęć, M. Trocki, K. Krajewski, Przedsiębiorczość w Polsce w perspektywie z integracją Europejską, Instytut Przedsiębiorczości i Samorządności, Warszawa 2003, s. 82.
} 
rynkowej na konkurencyjnym i nieprzewidywalnym rynku. Dostrzega się wagę elastyczności jako pożądanej własności organizacji. Formalne reguły, procedury, metody okazują się mniej przydatne w takim otoczeniu niż spontaniczne, niekonwencjonalne, kreatywne zachowania. Aby osiągnąć taki stan rzeczy konieczne jest wytworzenie $w$ organizacji przedsiębiorczej kultury organizacyjnej. Za Cz. Sikorskim ${ }^{17}$ w odniesieniu do pojęcia kultura organizacyjna stosować można dwa podejścia - ideowe i instytucjonalne. Przyjmując pierwszy punkt widzenia kultura jest cechą organizacji, w drugim zaś przypadku kultura jako rezultat ludzkich działań utożsamiana jest z samą organizacją. Zdaniem autorów bardziej zasadne i użyteczne jest traktowanie kultury jako pewnego podsystemu organizacji. Obejmuje on takie elementy, jak wzory myślenia, wzory zachowań i symbole ${ }^{18}$. Co będzie zatem charakteryzowało organizację gotową do funkcjonowania na rynku globalnym - organizację przedsiębiorczą? W odniesieniu do pierwszego z elementów - wzorów myślenia - wskazywać można na kształtowanie się zbiorów wartości, w których wysoką pozycję zajmują: sukces, praca, rozwój, niezależność, itd. Można też wskazywać na formułowanie reguł, które szczególnie w ujęciu prakseologicznym wskazują na konieczność wykazywania się profesjonalizmem, kompetencją, inwencją i skutecznością w działaniu. Kolejny element kultury - wzory zachowań - w organizacji przedsiębiorczej będą opierały się na ciągłym dążeniu do doskonalenia się i gotowości do zmian. Wreszcie można także wskazywać na trzeci z wymienionych przez Sikorskiego elementów - symbole. Bardzo charakterystyczne może być odwoływanie się do istotnych z punktu widzenia organizacji przedsiębiorczej symboli osobowych. Tworzy się $\mathrm{w}$ ten sposób organizacyjnych bohaterów przedsiębiorczości, do których można się odwoływać, których traktować można jako pewnego rodzaju wzorzec dla wszystkich pracowników organizacji. Wymienione obszary wydają się zatem niezmiernie istotne z punktu widzenia zarządzania organizacją przedsiębiorczą w globalizującej się rzeczywistości gospodarczej.

\section{LITERATURA}

Bartnicki M., Dyduch W., Przedsiębiorczość - element kultury organizacyjnej, Zarządzanie zasobami ludzkimi, Nr 3-4/2002.

Bombiak E., Pożądany wzorzec, Personel 1-15 lutego 2003.

Clarke L., Zarzadzanie zmiana, Gebethner i Ska, Warszawa 1997.

Cziomer E., Zyblikiewicz L. W., Zarys współczesnych stosunków międzynarodowych, Wydawnictwo Naukowe PWN, Warszawa-Kraków 2001.

Drucker P. F.,Innowacja i przedsiębiorczość, Państwowe Wydawnictwo Ekonomiczne, Warszawa 1992.

Drucker P. F., Menedżer skuteczny, Nowoczesność, Warszawa 1994.

Drucker P. F., Myśli przewodnie Druckera, Wydawnictwo MT Biznes, Warszawa 2002.

Drucker P. F., Praktyka zarządzania, Nowoczesność, Warszawa 1998.

Drucker P. F., Zarzadzanie w czasach burzliwych, Nowoczesność, Warszawa 1995.

Dyoniziak R., Iwanicka K., Karwińska A., Nikołajew J., Pucek Z., Społeczeństwo w procesie zmian, Zachodnie Centrum Organizacji, Zielona Góra 1999.

Gierszewska G., Romanowska M., Analiza strategiczna przedsiębiorstwa, Polskie Wydawnictwo Ekonomiczne, Warszawa 1998.

Golińska-Pieszyńska M., Przedsiębiorca i przedsiębiorczość - ewolucja pojęć, M. Trocki, K. Krajewski, Przedsiębiorczość w Polsce w perspektywie z integracją Europejską, Instytut Przedsiębiorczości i Samorządności, Warszawa 2003.

\footnotetext{
${ }^{17}$ Cz. Sikorski, Kultura organizacyjna, C. H. Beck, Warszawa 2002, s. 3

${ }^{18}$ Tamże, s. 7
} 
Hasselbein F., Goldsmith M., Beckhard R., Lider przyszłości, Bussines Press, Warszawa 1997.

Kamiński R., Kultura organizacyjna sprzyjająca innowacyjności w przedsiębiorstwie, Zarządzanie zasobami ludzkimi, $\mathrm{Nr}$ 2/2002.

Kaprowicz E., Menedżerowie w nowych rolach, Zarządzanie zasobami ludzkimi, Nr 2/2002.

Kozioł L., Piechnik-Kurdziel A., Kopeć J., Zarządzanie zasobami ludzkimi w firmie. Teoria $i$ praktyka, Wydawnictwo Biblioteczka Pracownicza, Warszawa 2000.

Łucewicz J., Socjologiczne spojrzenie na organizację, Wydawnictwo Akademii Ekonomicznej im. Oskara Langego we Wrocławiu, Wrocław 1997.

Machaczka J., Zarzadzanie rozwojem organizacji. Czynniki, modele, strategia, diagnoza, Wydawnictwo Naukowe PWN, Warszawa-Kraków 1998.

Masłyk-Musiał E., Społeczeństwo i organizacje. Socjologia organizacji i zarządzania, Wydawnictwo Uniwersytetu Marii Curie-Skłodowskiej, Lublin 1996.

Olszewski A., Pora na zespoły, Personel 16-31 stycznia 2003.

Pacholski M., Słaboń A., Słownik pojęć socjologicznych, Akademia Ekonomiczna w Krakowie, Kraków 1997.

Piasecki B., Przedsiębiorczość i mała firma. Teoria i praktyka, Wydawnictwo Uniwersytetu Łódzkiego, Łódź 1997.

Pietrzkiewicz T., Systemy wartości i kodeksy etyczne $w$ gospodarce, Instytut Organizacji i Zarządzania w Przemyśle ORGMASZ, Warszawa 1997.

Praca zbiorowa pod red. Marcinkowskiego A., Kapitalizm po polsku. Przedsiębiorca, organizacja, kultura, Księgarnia Akadmiska, Kraków 1996.

Praca zbiorowa pod red. J. Dietla, W. Gasparskiego, Etyka biznesu, Wydawnictwo Naukowe PWN, Warszawa 2000.

Sikorski Cz., Kultura organizacyjna, Wydawnictwo C H Beck, Warszawa 2002.

Sułkowski Ł., Czy kultury organizacyjne zmierzaja do unifikacji?, Zarządzanie zasobami ludzkimi, Nr 1/2002.

West M. A., Rozwijanie kreatywności wewnątrz organizacji, Wydawnictwo Naukowe PWN, Warszawa 2000. 